\title{
Genetic divergence in round tomato germplasm: optimization and hierarchical methods
}

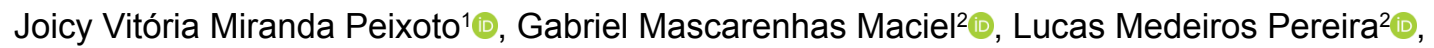

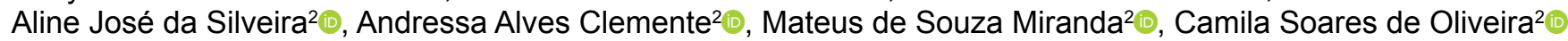

\footnotetext{
1 Universidade Federal de Uberlândia, Instituto de Ciências Agrárias, Campus Glória, Uberlândia, MG, Brasil. E-mail: joicyvmpeixoto@yahoo.com.br

2 Universidade Federal de Uberlândia, Instituto de Ciências Agrárias, Monte Carmelo, MG, Brasil. E-mail: gabrielmaciel@ufu.br; lucasmedeiros10394@gmail.com;

alinejoseagro@gmail.com; andressalves50@gmail.com; mateusmrd@outlook.com; camilaagroufu@gmail.com
}

ABSTRACT: The characterization of germplasm banks is essential for successful breeding programs. There is no consensus on which multivariate analysis method is the most appropriate to characterize a round tomato germplasm bank. This study aimed to characterize the genetic divergence between tomato accessions to assess whether there is agreement between the hierarchical and optimization methods and to recommend promising combinations for obtaining hybrids. The experiment was conducted at the Experimental Vegetable Station of the Federal University of Uberlândia in 2016. The experimental design was a randomized block design with 32 treatments, including 31 tomato genotypes and a commercial control (cv. Rio Grande), with four replicates. The results showed genetic variability between genotypes. The UPGMA hierarchical method allowed greater discrimination between genotypes. Crossing the genotypes UFU-85\#9 salada-D, UFU-91\#5 salada-D, and cv. Rio Grande will lead to hybrids with high chlorophyll content, high yield, high fruit mass, and fruits with high soluble solids.

\section{Divergência genética em germoplasma de tomateiro tipo salada: métodos de otimização e hierárquico}

RESUMO: A caracterização de bancos de germoplasma é fundamental para que se tenha sucesso no programa de melhoramento. Entretanto, não há um consenso sobre qual metodologia de análise multivariada é a mais adequada para caracterizar um banco de germoplasma de tomateiro do tipo salada. Assim, este trabalho foi realizado com o objetivo de caracterizar a divergência genética entre os acessos de tomateiro, verificar se existe coerência entre os métodos hierárquicos e de otimização aplicados e indicar combinações promissoras para a obtenção de híbridos. 0 ensaio foi conduzido na Estação Experimental de Hortaliças da Universidade Federal de Uberlândia, em 2016. O delineamento experimental foi em blocos casualizados com 32 tratamentos, sendo 31 genótipos de tomateiro e uma testemunha comercial (cv. Rio Grande) com quatro repetições. Concluiu-se que existe variabilidade genética entre os genótipos. 0 método hierárquico UPGMA permitiu maior discriminação entre os genótipos. 0 cruzamento entre os genótipos UFU-85\#9 salada-D, UFU-91\#5 salada-D e cv. Rio Grande possibilitará a obtenção de híbridos com alto teor de clorofila, alta produtividade, massa de frutos e frutos com alto teor de sólidos solúveis.

Palavras-chave: Solanum lycopersicum; tomate de mesa; variabilidade 


\section{Introduction}

The tomato (Solanum lycopersicum L.) is the most cultivated and consumed vegetable in the world, so it has high socioeconomic importance (Alvarenga et al., 2013). The market value of seeds of tomato cultivars is estimated at more than $\mathrm{R} \$ 120$ million. In 2017, Brazilian production reached almost four million tons of fruit produced throughout the national territory (IBGE, 2017). The tomato has a wide diversity of fruit characteristics, which is why it is classified into commercial groups: Santa Cruz (chonto), Caqui (beefsteak), Salada (round), Saladete (Italian; saladette or roma), and Minitomate (cherry or grape) (Alvarenga et al., 2013). Commercially, the round tomato has predominated and is the one preferred by consumers. In 2017, more than 58,000 hectares of tomato were cultivated in Brazil (IBGE, 2017).

The main form of tomato production has been the use of hybrids, with the exploration of heterosis effects. Tomato hybrids have significant heterosis values capable of promoting higher yields (Maciel et al., 2010). To efficiently explore the effects of heterosis, prior identification of homozygous and contrasting lines is necessary. For this, it is necessary to have genetic variability and improved lines that are conducive to these goals (Maciel et al., 2010). Genetic variability determines the feasibility of a breeding program and is enhanced by intercrossing between contrasting genotypes (Silva \& Dias, 2013).

In this context, multivariate techniques have been used to estimate the genetic divergence between accessions using biometric models estimated by Euclidean distance and hierarchical clustering methods (Cruz et al., 2014). The Tocher and unweighted pair group method with arithmetic mean (UPGMA) methods are often used to visualize genetic divergence in tomato genotypes (Araújo et al., 2016). However, there is no consensus about the best clustering method for evaluating round tomato germplasm.

The objectives of this study were to characterize the genetic divergence between tomato genotypes, to assess whether there is agreement between the hierarchical and optimization methods applied, and to recommend promising combinations for obtaining hybrids.

\section{Materials and Methods}

The experiments were conducted at the Experimental Vegetable Station of the Federal University of Uberlândia (UFU), Monte Carmelo campus, in 2016 (18 42'43.19"S; $47^{\circ} 29^{\prime} 55.8^{\prime \prime} \mathrm{W} ; 873 \mathrm{~m}$ altitude). The germplasm used is part of the round tomato breeding program of the UFU. The genotypes were obtained following the genealogical method until the fifth self-fertilization in 2016. The period in which generations were advanced was 2013 to 2016. The agronomic experiment was conducted in January 2016, with 31 tomato genotypes and one control, the commercial cultivar Rio Grande (cv. Rio Grande), totaling 32 treatments. The soil where the agronomic experiment was conducted had the following characteristics: $\mathrm{pH}\left(\mathrm{H}_{2} \mathrm{O}\right)=5.9$; available $\mathrm{P}=30.1 \mathrm{mg}$ $\mathrm{dm}^{-3} ; \mathrm{K}=0.22 \mathrm{cmol}_{\mathrm{c}} \mathrm{dm}^{-3} ; \mathrm{Ca}^{+2}=2.8 \mathrm{cmol}_{\mathrm{c}} \mathrm{dm}^{-3} ; \mathrm{Mg}=1.0 \mathrm{cmol}_{\mathrm{c}}$ $\mathrm{dm}^{-3}$; exchangeable $\mathrm{H}+\mathrm{Al}=3.40 \mathrm{cmol}_{\mathrm{c}} \mathrm{dm}^{-3}$; organic matter $=4.2 \mathrm{dag} \mathrm{kg}^{-1}$; SMP index = 3.40; aluminum $=0.0 \mathrm{cmol}_{\mathrm{c}} \mathrm{dm}^{-3}$; CEC pH $7.0=7.42 \mathrm{cmol}_{c} \cdot \mathrm{dm}^{-3}$; base saturation $=54 \%$; effective aluminum saturation $=0 \%$; copper $=2.3 \mathrm{mg} \mathrm{dm}^{-3}$; zinc $=6.6$ $\mathrm{mg} \mathrm{dm}^{-3}$, and manganese $=6.6 \mathrm{mg} \mathrm{dm}^{-3}$.

The 32 genotypes were sown in 200-cell polystyrene trays containing coconut fiber-based commercial substrate on January 20, 2016. The trays were placed in an arched greenhouse 7 wide by $21 \mathrm{~m}$ long, with a 4-m-high ceiling that was covered with a clear $150-\mu \mathrm{m}$ polyethylene film, with additives against ultraviolet rays, and side curtains made of white anti-aphid screen. After 31 days of sowing, the seedlings were transplanted to the field. The field had been previously prepared by plowing and harrowing. The spacing used was $1.5 \mathrm{~m}$ between rows and $0.22 \mathrm{~m}$ between plants, and the plants were cultivated in a single row of prostrate plants. Each experimental plot was $5.28 \mathrm{~m}^{2}$ (3.52 m long and $1.5 \mathrm{~m}$ wide), consisting of 16 plants, only the 12 central plants being evaluated. The experiment totaled 2048 plants over an area of $676 \mathrm{~m}^{2}$. Throughout the experiment, crop management was performed as recommended for the tomato crop (Alvarenga et al., 2013). Pest control was performed by monitoring and applying chemical pesticide only when necessary. Irrigation was performed as required by the crop, i.e., when the soil water tension reached values between $25 \mathrm{kPa}$ and $40 \mathrm{kPa}$ (Marouelli et al., 2011).

The following agronomic traits were evaluated:

SPAD index at flowering and fruiting: mean value obtained after collecting data from the 12 central plants of each plot. This parameter was measured in the morning in leaves from the apex, the middle part, and the basal part of the tomato plant, using one leaf per measurement. The Minolta SPAD-502 CFL1030 chlorophyll meter was used.

Leaf temperature $\left({ }^{\circ} \mathrm{C}\right)$ in the vegetative and reproductive phase: obtained using an infrared thermometer (model 4000.4GL, Everest Interscience, Tucson, AZ, USA), by sampling the upper portion of two leaves per plant and pointing the sensor to the central portion of the leaf surface. This evaluation was performed in the morning.

Average fruit mass $(\mathrm{kg})$ : ratio between weight and number of all fruits harvested from the plot.

Production per plant $\left(\mathrm{kg} \mathrm{plant}^{-1}\right)$ : ratio between the mass of the harvested fruits and the number of plants in the plot.

Number of fruits per plant (fruits plant ${ }^{-1}$ ): ratio between the total number of fruits and the number of plants in the plot.

Internode distance $(\mathrm{cm})$ : measurement of the distance between all nodes of the plant, located from the beginning of the bifurcation of the stems, to the first leaf just below the last inflorescence. This parameter was determined at the end of the crop cycle.

Total soluble solid content ( $\left.{ }^{\circ} \mathrm{Brix}\right)$ : average of five fruits harvested from all plants in the plot, using a portable digital refractometer (Atago PAL-1 3810). 
The experimental design was a randomized block design with 32 treatments and four replicates. The data were analyzed by analysis of variance and the $F$ test ( $p \leq 0.05$ ). The means were compared in two different ways, by the Scott-Knott test $(p=0.05)$ and by the Dunnett test $(p=0.05)$, to compare the performance of the genotypes between themselves and compared with the control, respectively. Subsequently, multivariate analyses were performed to determine the genetic dissimilarity between genotypes using the Euclidean distance dissimilarity matrix. The genetic divergence was represented by a dendrogram obtained by the UPGMA method and by the Tocher optimization method. The clustering by the UPGMA method was validated using the cophenetic correlation coefficient (CCC), calculated by the Mantel test (1967). The relative contribution of quantitative traits was calculated according to Singh (1981). All data were analyzed with Genes v. 2015.5.0 (Cruz, 2013).

\section{Results and Discussion}

The analysis of variance revealed a difference between the tomato genotypes in the variables SPAD index and leaf temperature in both the vegetative and reproductive stages, as well as internode distance, production per plant, and average fruit mass per plant. The genotypes, when compared individually with the commercial cultivar Rio Grande (T32 = cV. Rio Grande) using the Dunnett test at 5\% probability, differed from the control in the abovementioned traits and in the soluble solid content. The number of fruits per plant and the soluble solid content of the fruits did not differ between the experimental genotypes according to the Scott-Knott test at $5 \%$ probability (Table 1 ).

The genotypes UFU-85\#9 salada-D, UFU-85\#4 salada-D, UFU-85\#6 salada-D, cv. Rio Grande, UFU-85\#5 salada-D, and UFU-86\#6 salada-D showed the highest levels of chlorophyll (SPAD index) in the vegetative phase. In this stage, the genotypes with the highest leaf temperatures were UFU$85 \# 9$ salada-D, Cv. Rio Grande, and UFU-86\#7 salada-D. In the reproductive phase, the highest SPAD indices were observed in UFU-2\#12 salada-D, cv. Rio Grande, UFU-86\#6 salada-D, UFU-79\#2 Santa Cruz-D, UFU-105\#4 Santa Cruz-D, UFU-93\#2 saladete-D, UFU-105\#1 Santa Cruz-D, UFU-85\#4 salada-D, UFU-91\#3 salada-D, UFU-86\#2 salada-D, and UFU-14\#1 salada-D (Table 1).

Table 1. Means of nine traits evaluated in the vegetative and reproductive stages in 32 tomato genotypes.

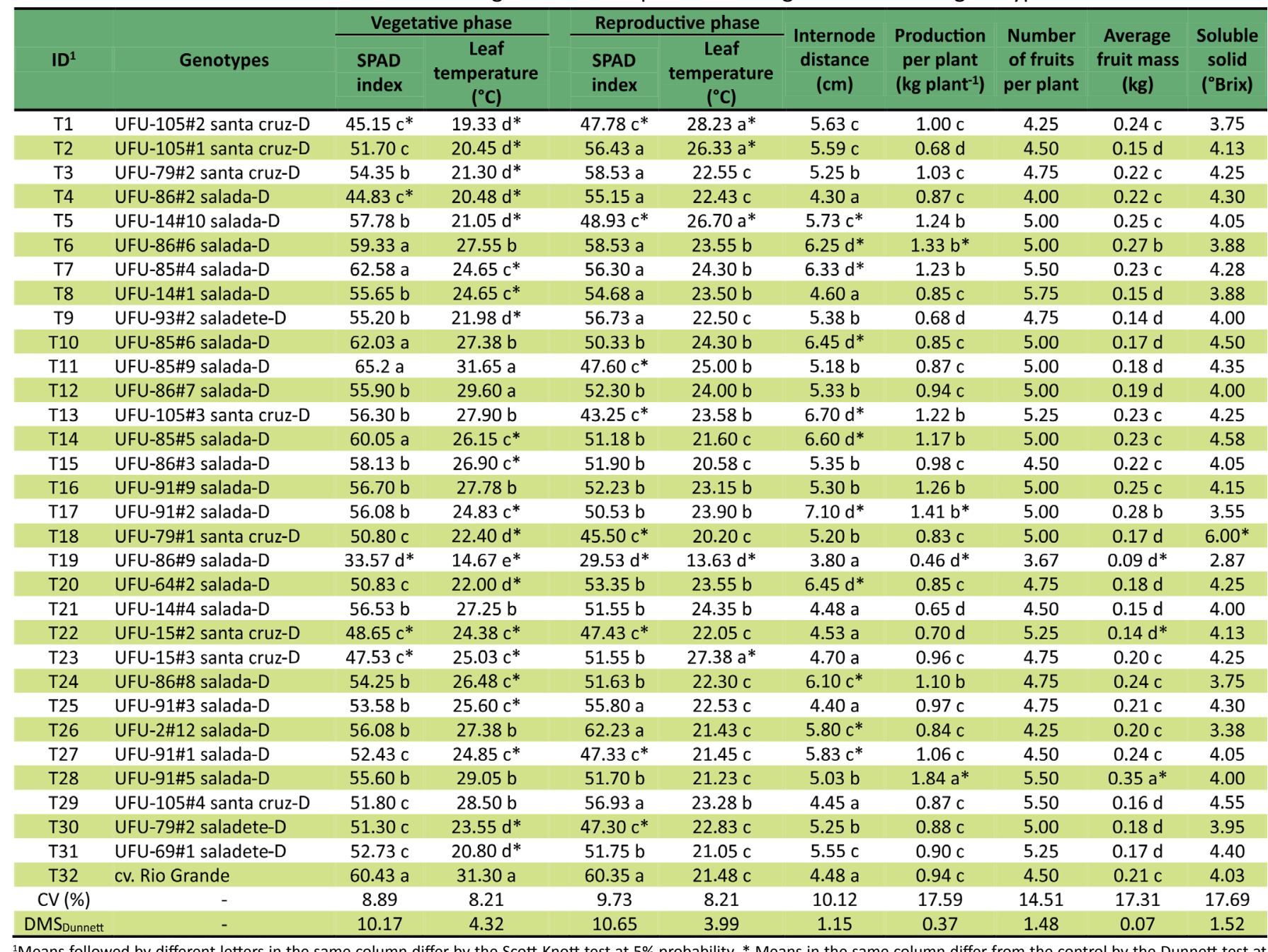

${ }^{1}$ Means followed by different letters in the same column differ by the Scott-Knott test at $5 \%$ probability. ${ }^{*}$ Means in the same column differ from the control by the Dunnett test at $5 \%$ probability. 
The leaf temperature in the reproductive phase of tomato plants was higher in UFU-105\#2 Santa Cruz-D, UFU-15\#3 Santa Cruz-D, UFU-14\#10 salada-D, and UFU-105\#1 Santa Cruz-D. The UFU-86\#9 salada-D genotype had the lowest mean SPAD index and mean leaf temperature in both the vegetative and reproductive phases. These results were similar to those from the Dunnett test (Table 1).

The lowest SPAD index values in the reproductive phase relative to the control (cv. Rio Grande) value were found in UFU-14\#10 salada-D, UFU-105\#2 Santa Cruz-D, UFU-85\#9 salada-D, UFU-15\#2 Santa Cruz-D, UFU-91\#1 salada-D, UFU79\#2 saladete-D, UFU-79\#1 Santa Cruz-D, UFU-105\#3 Santa Cruz-D, and UFU- 86\#9 salada-D. The lowest SPAD index in the vegetative phase relative to the control (cv. Rio Grande) value was found in UFU-15\#2 Santa Cruz-D, UFU-15\#3 Santa Cruz-D, UFU-105\#2 Santa Cruz-D, UFU-86\#2 salada-D and UFU-86\#9 salada-D. These genotypes together with UFU-86\#3 salada-D, UFU-86\#8 salada-D, UFU-85\#5 salada-D, UFU-91\#3 salada-D, UFU-91\#1 salada-D, UFU-91\#2 salada-D, UFU-85\#4 salada-D, UFU-14\#1 salada-D, UFU-79\#2 saladete-D, UFU-79\#1 Santa Cruz-D, UFU-64\#2 salada-D, UFU-93\#2 saladete-D, UFU-79\#2 Santa Cruz-D, UFU-14\#10 salada-D, UFU-69\#1 saladete-D, and UFU-105\#1 Santa Cruz-D presented the lowest leaf temperatures in the vegetative stage (Table 1).

The SPAD index provides information on the nitrogen content present in the leaf. This has a significant correlation with the intensity of green color and the chlorophyll content (Peixoto et al., 2017a). Nitrogen is essential for plant growth and development, favoring leaf development, improving photosynthetic capacity, and consequently raising its yield (Bastos et al., 2013). This macronutrient is absorbed in high amounts both in the vegetative and reproductive phases of the crop (Grigorita, 2014).

The chlorophyll content (SPAD) observed by Ramos (2013) at 45 days after transplanting (DAT), the beginning of fruiting, in tomato leaves from the hybrid 'Giuliana' was 46.20, and at 96 DAT (peak of harvest) it was 54.91. In the present study, approximately $90 \%$ of the studied genotypes in the vegetative phase had leaf chlorophyll contents higher than 46.20. In the reproductive phase, ten genotypes showed values higher than 54.91, with the highest chlorophyll content in the leaves of the control (cv. Rio Grande), which was 9\% higher than the value found by Ramos (2013).

Plants absorb energy directly from sunlight and the infrared radiation from the environment. Some of this energy absorbed by the leaf is converted into photoassimilates, and the excess is dissipated to the environment in the form of heat, avoiding damage to the photosynthetic apparatus (Taiz et al., 2017). Leaf temperature is one of the physiological indicators of the water status of a plant. The increase in leaf temperature is correlated with low transpiration $(r=-0.95)$, and transpiration is the main heat loss mechanism of these organisms (Morales et al., 2015).

In this study, the UFU-86\#9 salada-D genotype had the lowest mean SPAD index and mean leaf temperature in both the vegetative and reproductive phases. This probably resulted in reduced fruit production and mass. In contrast, the UFU-91\#5 salada-D genotype showed high values of the SPAD index in the vegetative and reproductive phases and of leaf temperature in the vegetative phase. This promoted an increase in fruit production per plant and fruit mass.

The shortest internode distance was observed in the genotypes UFU-15\#3 Santa Cruz-D, UFU-14\#1 salada-D, UFU15\#2 Santa Cruz-D, cv. Rio Grande, UFU-14\#4 salada-D, UFU105\#4 Santa Cruz-D, UFU-91\#3 salada-D, UFU-86\#2 salada-D, and UFU-86\#9 salada-D. UFU-91\#2 salada-D, UFU-105\#3 Santa Cruz-D, UFU-85\#5 salada-D, UFU-64\#2 salada-D, UFU-85\#6 salada-D, UFU-85\#4 salada-D and UFU-86\#6 salada-D had the longest internode distance. These genotypes, together with UFU-86\#8 salada-D, UFU-91\#1 salada-D, UFU-2\#12 salada-D, and UFU-14\#10 salada-D, showed greater internode distance than the control (cv. Rio Grande) (Table 1).

Reducing the internode distance results in more compact tomato plants, facilitating crop management in the field (Figueiredo et al., 2015), in addition to reducing costs for the producer. The internode distance, number of fruits per plant, production per plant, and fruit mass are traits directly related to fruit yield and quality (Rai et al., 2017). In the present study, the UFU-91\#5 salada-D genotype showed a small internode distance $(5.03 \mathrm{~cm})$, and this accession produced the fruits with the greatest mass $(0.35 \mathrm{~kg})$ and consequently the highest fruit production per plant $(1.84 \mathrm{~kg})$. The UFU-91\#5 salada-D genotype had the highest average fruit production per plant and fruit mass. The genotypes UFU-15\#2 Santa Cruz-D, UFU-105\#1 Santa Cruz-D, UFU-93\#2 saladete-D, UFU14\#4 salada-D, and UFU-86\#9 salada-D had the lowest fruit production per plant. Those genotypes together with UFU86\#7 salada-D, UFU-64\#2 salada-D, UFU-79\#2 saladete-D, UFU-85\#9 salada-D, UFU-69\#1 saladete-D, UFU- 79\#1 Santa Cruz-D, UFU-85\#6 salada-D, UFU-105\#4 Santa Cruz-D, and UFU-14\#1 salada-D had the lowest mean fruit masses (Table 1).

Among the 32 genotypes studied, three showed greater production per plant than the control (cv. Rio Grande). The genotypes UFU-91\#2 salada-D and UFU-86\#6 salada-D were, respectively, $50 \%$ and $41 \%$ higher than the control on this measure. UFU-91\#5 salada-D showed almost twice the fruit production per plant as the control and a fruit mass $66 \%$ higher than the control. In contrast, the UFU-86\#9 salada-D genotype, when compared to the control, showed the lowest fruit production per plant. This genotype together with UFU15\#2 Santa Cruz-D presented the fruits with a lower average fruit mass than the control.

Positive values for the genotypic and phenotypic correlation between the traits fruit yield per plant, number of fruits per plant, average fruit mass, and pericarp thickness of the tomato fruit contribute to increased yield. These traits should be considered together as a primary yield component in tomato breeding (Souza et al., 2012). The number of fruits per plant affects the size of the fruit and its mass, influencing the production yield (Peixoto et al., 2017b). That study aligns with the results found in the present study, in which the UFU- 
91\#5 salada-D genotype had the highest fruit production (1.84 kg of tomato per plant) and had the highest average fruit mass $(0.35 \mathrm{~kg})$.

The UFU-79\#1 Santa Cruz-D genotype showed higher soluble solid content than the control (cv. Rio Grande) (Table 1). Soluble solids consist mainly of sugars (approximately 85 to $90 \%$ ) (Chitarra \& Chitarra, 2005). The sugars stored in tomato fruits are the main attribute of postharvest quality and are directly related to their flavor (Ramos et al., 2013). Soluble solids influence yield, consistency, and product quality (Siddiqui et al., 2015). The genotypes that produce fruits with soluble solid content above $3^{\circ}$ Brix may be sold in the fresh fruit market (Schwarz et al., 2013). Of the 32 genotypes evaluated in the present study, only UFU-86\#9 salada-D showed soluble solid content below $3^{\circ}$ Brix.

The dendrogram obtained by the UPGMA method was generated from the dissimilarity matrix using the Euclidean distance. The cophenetic correlation coefficient observed was $87 \%$, with $19.1 \%$ distortion, demonstrating an adequate relationship between the distance matrix and the generated dendrogram (Figure 1).

The groups were separated with a cutoff of $50 \%$ dissimilarity between the genotypes. The cutoff was established at the site where there was an abrupt change in the branches in the dendrogram (Cruz et al., 2014). Using this cutoff, the genotypes were clustered into four distinct groups. Group I had $53 \%$ of the genotypes. Group II had the genotypes UFU-14\#1 salada-D, UFU-86\#7 salada-D, UFU-91\#9 salada-D,
UFU-14\#4 salada-D, UFU-15\#2 Santa Cruz-D, UFU-15\#3 Santa Cruz-D, UFU-91\#3 salada-D, UFU-105\#4 Santa Cruz-D, and UFU-79\#2 saladete- D. Group III had UFU-85\#9 salada-D, UFU91\#5 salada-D, and the control cv. Rio Grande. Group IV had UFU-105\#2 Santa Cruz-D, UFU-105\#1 Santa Cruz-D, and UFU14\#10 salada-D.

The use of genotypes UFU-85\#9 salada-D, UFU-91\#5 salada-D, and cv. Rio Grande as parents is viable due to their divergence from the other genotypes. The genotypes UFU85\#9 salada-D and cv. Rio Grande showed high chlorophyll content in the leaves (SPAD index) and high leaf temperature in the vegetative phase. The Rio Grande cultivar also showed high chlorophyll content in the leaf in the reproductive phase and a shorter internode distance. The UFU-85\#9 salada-D genotype had the best intermediate values for leaf temperature in the reproductive phase and internode distance. The genotype UFU-91\#5 salada-D showed the best intermediate values for leaf chlorophyll content (SPAD index) in both the vegetative and reproductive phases, leaf temperature in the vegetative phase, and internode distance. This genotype had the highest mean fruit production per plant and fruit mass (Table 1), indicating that it is a promising genotype that can enable favorable increases in these traits in crosses. The clustering by the Tocher method was distinct from the one obtained by UPGMA, forming two groups (Table 2).

The first group consisted of 31 genotypes, approximately $97 \%$, while the second group was formed only by UFU-86\#9 salada-D. It was difficult to characterize the divergence

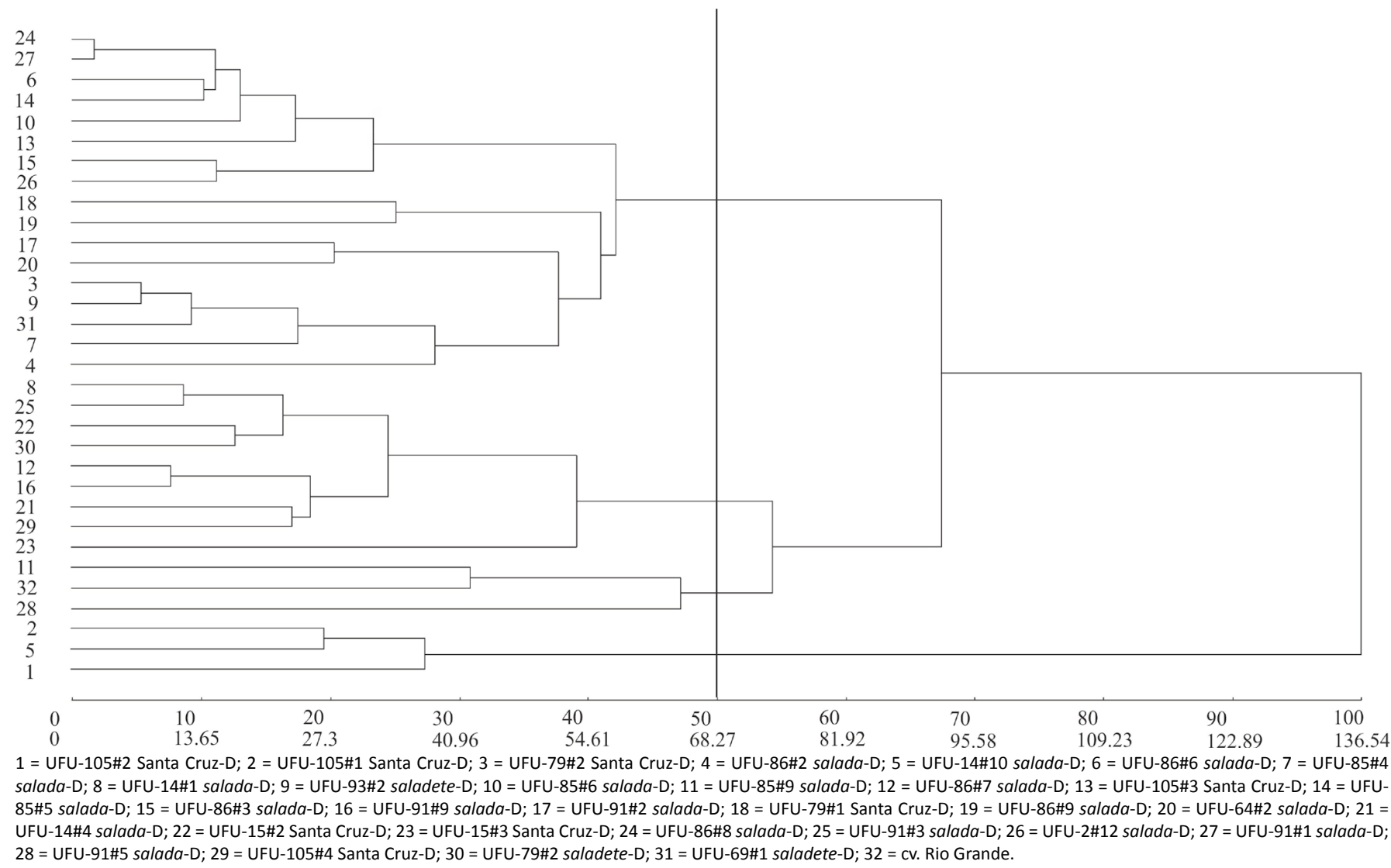

Figure 1. Dendrogram illustrating the analysis of 32 tomato genotypes using the average linkage clustering (UPGMA) method obtained with the mean Euclidean distance generated with nine traits. 
Table 2. Clustering of 32 genotypes of round tomato plants for fresh consumption by Tocher's optimization method using the Euclidean distance.

\begin{tabular}{|c|c|}
\hline Group & Genotypes \\
\hline 1 & $1 ; 2 ; 3 ; 4 ; 5 ; 6 ; 7 ; 8 ; 9 ; 10 ; 11 ; 12 ; 13 ; 14 ; 15 ; 16 ; 17 ; 18 ; 20 ; 21 ; 22 ; 23 ; 24 ; 25 ; 26 ; 27 ; 28 ; 29 ; 30 ; 31$ and cv. Rio Grande \\
\hline II & 19 \\
\hline
\end{tabular}

1 = UFU-105\#2 Santa Cruz-D; 2 = UFU-105\#1 Santa Cruz-D; 3 = UFU-79\#2 Santa Cruz-D; 4 = UFU-86\#2 salada-D; 5 = UFU-14\#10 salada-D; 6 = UFU-86\#6 salada-D; 7 = UFU-85\#4 salada-D; 8 = UFU-14\#1 salada-D; $9=$ UFU-93\#2 saladete-D; $10=$ UFU-85\#6 salada-D; 11 = UFU-85\#9 salada-D; $12=$ UFU-86\#7 salada-D; $13=$ UFU-105\#3 Santa Cruz-D; $14=$ UFU85\#5 salada-D; 15 = UFU-86\#3 salada-D; 16 = UFU-91\#9 salada-D; $17=$ UFU-91\#2 salada-D; $18=$ UFU-79\#1 Santa Cruz-D; $19=$ UFU-86\#9 salada-D; 20 = UFU-64\#2 salada-D; 21 = UFU-14\#4 salada-D; 22 = UFU-15\#2 Santa Cruz-D; 23 = UFU-15\#3 Santa Cruz-D; $24=$ UFU-86\#8 salada-D; $25=$ UFU-91\#3 salada-D; 26 = UFU-2\#12 salada-D; 27 = UFU-91\#1 salada-D; $28=$ UFU-91\#5 salada-D; 29 = UFU-105\#4 Santa Cruz-D; 30 = UFU-79\#2 saladete-D; $31=$ UFU-69\#1 saladete-D; $32=\mathrm{cv}$. Rio Grande.

between genotypes since most of them were found in only one group.

The selection criterion by the Tocher method includes in the initial group the most homogeneous pair of genotypes identified in the dissimilarity matrix. From this starting point, it is possible to include new individuals following the criterion that the mean intragroup distance be less than the mean intergroup distance (Cruz et al., 2014). This result in most genotypes being clustered into a few groups, and groups with only one genotype can arise, as occurred in this study. In a study of the genetic divergence between 13 tomato hybrids for industrial processing, Luz et al. (2016) also observed a predominance of genotypes in one group (61\%) and the formation of groups with only one genotype when using the Tocher method. Amaral Júnior et al. (2017), when characterizing the genetic diversity of 15 tomato genotypes by the Tocher method, observed the same trend.

The UPGMA method aims to cluster the genotypes into groups according to the classification criterion so that there is homogeneity within each group and heterogeneity between groups. The dendrograms are generated by fitting models with the lowest dissimilarity (Cruz et al., 2014). Thus, this method can form more groups from a given number of genotypes, as observed in this study.

Based on the criterion proposed by Singh (1981), the most important traits for genotype discrimination were internode distance $(17.02 \%)$, leaf temperature $\left({ }^{\circ} \mathrm{C}\right)$ in the vegetative phase (13.68\%), and number of fruits per plant (13.17\%) (Table $3)$. This probably explains the clustering of the genotypes UFU85\#9 salada-D, UFU-91\#5 salada-D, and cV. Rio Grande in the UPGMA dendrogram (Figure 1), since these genotypes were similar in the traits that made greater relative contributions to the divergence between the genotypes.

Table 3. Relative contribution (\%) of traits to the genetic divergence in tomato genotypes for fresh consumption, estimated by the method proposed by Singh (1981).

\begin{tabular}{lcc}
\hline \multicolumn{1}{c}{ Variables analyzed } & S.j & S.j (\%) \\
\hline Distance between internodes (cm) & 60.01 & 17.02 \\
Leaf temperature $\left({ }^{\circ} \mathrm{C}\right)$ in vegetative phase & 48.22 & 13.68 \\
Number of fruits per plant & 46.43 & 13.17 \\
Average fruit mass $(\mathrm{kg})$ & 37.66 & 10.68 \\
Production per plant $(\mathrm{kg})$ & 36.17 & 10.26 \\
SPAD index in vegetative phase & 36.16 & 10.26 \\
SPAD index in reproductive phase & 33.45 & 9.49 \\
Leaf temperature $\left({ }^{\circ} \mathrm{C}\right)$ in reproductive phase & 30.58 & 8.67 \\
Soluble solids content $\left({ }^{\circ} \mathrm{BRIX}\right)$ & 23.84 & 6.76 \\
\hline
\end{tabular}

SPAD index and leaf temperature in both the vegetative and reproductive phases had the highest range and standard deviation values (Table 4). This indicates high diversity between the genotypes in these traits.

The soluble solid content was the trait that contributed the least $(6.76 \%)$ to the genetic divergence between the studied genotypes (Table 3 ). This variable had one of the smallest ranges and lowest standard deviation values (Table 4 ), demonstrating similarity between the genotypes on this quality attribute. The result of the $\mathrm{F}$ test and the comparison of means by Scott-Knott confirmed this hypothesis.

In a study with tomato hybrids with indeterminate growth habits, Andrade et al. (2014) observed low standard deviation values for total production (0.49) and soluble solid content (0.03). That study aligns with the results of the present study, in which the variables production per plant, number of fruits per plant, and soluble solid content had the lowest standard deviation values, at $0.26,0.45$, and 0.49 , respectively.

Table 4. Descriptive statistical analysis for agronomic traits of tomato genotypes.

\begin{tabular}{ccccc}
\hline Variable & Minimum & Maximum & Amplitude & $\begin{array}{c}\text { Standard } \\
\text { deviation }\end{array}$ \\
\hline SPAD VP & 33.57 & 65.2 & 31.63 & 6.04 \\
SPAD RP & 29.53 & 62.22 & 32.69 & 6.00 \\
\hline LTV $\left({ }^{\circ} \mathrm{C}\right)$ & 14.67 & 31.65 & 16.98 & 3.74 \\
LTR $\left({ }^{\circ} \mathrm{C}\right)$ & 13.63 & 28.22 & 14.59 & 2.56 \\
ID $(\mathrm{cm})$ & 3.80 & 7.10 & 3.30 & 0.81 \\
PP & 0.46 & 1.84 & 1.38 & 0.26 \\
NFP & 3.67 & 5.75 & 2.08 & 0.45 \\
AFM & 0.09 & 0.34 & 0.26 & 0.50 \\
\hline SS & 2.87 & 6.00 & 3.13 & 0.49 \\
\hline
\end{tabular}

${ }^{1}$ SPAD VP = SPAD index in the vegetative phase; SPAD RP = SPAD index in the reproductive phase; $L T V=$ leaf temperature in the vegetative phase $\left({ }^{\circ} \mathrm{C}\right)$; $L T R=$ leaf temperature in the reproductive phase $\left({ }^{\circ} \mathrm{C}\right) ; \mathrm{ID}=$ internode distance $(\mathrm{cm}) ; \mathrm{PP}=$ production per plant $(\mathrm{kg}$ plant $\left.^{-1}\right) ; \mathrm{NFP}=$ number of fruits per plant; AFM = average fruit mass $(\mathrm{kg}) ; \mathrm{SS}=$ soluble solid content ( $\left.{ }^{\circ} \mathrm{BRIX}\right)$,

\section{Conclusions}

The multivariate UPGMA and Tocher's optimization methods indicated that the genotypes have genetic variability.

The UPGMA hierarchical method showed greater discrimination power, allowing the identification of more groups containing similar accessions.

The combination of genotypes UFU-85\#9 salada-D, UFU91\#5 salada-D, and cv. Rio Grande is recommended to produce hybrids with high chlorophyll content and consequently higher photosynthetic efficiency, high yield, high fruit mass, and fruits with a high content of soluble solids. 


\section{Literature Cited}

Alvarenga, M.A.R. Tomate: produção em campo, casa de vegetação e hidroponia. Lavras: Editora Universitária de Lavras, 2013. 455p.

Amaral Júnior, A.T.; Graça, A.J.P.; Vivas, M.; Viana, A.P.; Rodrigues, R. Prospecting of tomato hybrids for table and industry via mixed modeling and multivariate analysis. Horticultura Brasileira, v.35, n.1, p.20-25, 2017. https://doi.org/10.1590/S0102-053620170104.

Andrade, M.C.; Silva, A.A.; Conrado, T.V.; Maluf, W.R.; Andrade, T.M.; Oliveira, C.M. Capacidade combinatória de linhagens de tomateiro em híbridos do tipo italiano. Bragantia, v.73, n.3, p.237-245, 2014. https://doi.org/10.1590/1678-4499.0039.

Araujo, J.C.; Telhado, S.F.P.; Sakai, R.H.; Ledo, C.A.S.; Melo, P.C.T. Univariate and multivariate procedures for agronomic evaluation of organically grown tomato cultivars. Horticultura Brasileira, v.34, n.3, p.374-380, 2016. https://doi.org/10.1590/S0102-05362016003011.

Bastos, A.R.R.; Alvarenga, M.A.R.; Carvalho, J.G.; Pinho, P.J. Nutrição mineral e adubação. In: Alvarenga, M.A.R. (Org.). Tomate: produção em campo, casa de vegetação e hidroponia. Lavras: Editora Universitária de Lavras, 2013. v.1, p.65-123.

Chitarra, M.I.F.; Chitarra, A.B. Qualidade pós-colheita. In: Chitarra, M.I.F.; Chitarra, A.B. (Eds.). Pós-colheita de frutas e hortaliças: Fisiologia e manuseio. 2.ed. Lavras- MG: UFLA, 2005. p.541-734.

Cruz, C.D. Genes: a software package for analysis in experimental statistics and quantitative genetics. Acta Scientiarum, v.35, n.3, p.271-276, 2013. https://doi.org/10.4025/actasciagron.v35i3.21251.

Cruz, C.D.; Carneiro, P.C.S.; Regazzi, A.J. Modelos biométricos aplicados ao melhoramento genético. Viçosa: UFV, 2014. 668p.

Figueiredo, A.S.T.; Meert, L.; Paula, J.T.; Resende, J.T.V.; Rodrigues, J.D.; Ono, E.O. Comportamento de plantas de tomateiro indeterminado na presença de regulador de crescimento. Revista Ciências Exatas e da Terra e Ciências Agrárias, v.10, n.1, p.3140, 2015. http://revista.grupointegrado.br/revista/index.php/ campodigital/article/view/1830. 09 Mar. 2018.

Grigorita, A.A. Research on the differentiation of accumulation of dry matter and nutrients in the foliary-fertilized tomato plant grown in the field. Journal of Horticulture, Forestry and Biotechnology, v.18, n.4, p.37-42, 2014. https://www.journal-hfb.usab-tm.ro/romana/2014/ Lista\%20lucrari\%20PDF/Vol\%2018(4)\%20PDF/10Ardelean\%20 Alina\%20Grigorita\%201_BUN.pdf. 09 Mar. 2018.

Instituto Brasileiro de Geografia e Estatística - IBGE. Levantamento sistemático da produção Agrícola: pesquisa mensal de previsão e acompanhamento das safras agrícolas no ano civil. 2017. Rio de Janeiro: IBGE, 2017. 81p. ftp://ftp.ibge.gov.br/Producao_ Agricola/Levantamento_Sistematico_da_Producao_Agricola_ [mensal]/Fasciculo/2017/Ispa_201701.pdf. 08 Dez. 2018.

Luz, J.M.Q.; Bittar, C.A.; Oliveira, R.C.; Nascimento, A.R.; Nogueira, A.P.O. Desempenho e divergência genética de genótipos de tomate para processamento industrial. Horticultura Brasileira, v.34, n.4, p.483-490, 2016. https://doi.org/10.1590/S0102-053620160406.

Maciel, G.M.; Maluf, W.R.; Silva, V. de F.; Gonçalves Neto, A.C.; Nogueira, D.W.; Gomes, L.A.A. Heterose e capacidade combinatória de linhagens de tomateiro ricas em acilaçúcares. Ciência e Agrotecnologia, v.34, n.5, p.1161-1167, 2010. https:// doi.org/10.1590/S1413-70542010000500012.
Mantel, N. The detection of disease clustering and a generalized regression approach. Cancer Research, v.27, n.2, p.209-220, 1967. http://cancerres.aacrjournals.org/content/27/2_Part_1/209. full-text.pdf. 09 Mar. 2018.

Marouelli, W.A.; Medeiros, M.A. de; Souza, R.F. de; Resende, F.V. Produção de tomateiro orgânico irrigado por aspersão e gotejamento, em cultivo solteiro e consorciado com coentro. Horticultura Brasileira, v.29, n.3, p.429-434, 2011. https://doi. org/10.1590/S0102-05362011000300029.

Morales, R.G.F.; Resende, L.V.; Bordini, I.C.; Galvão, A.G.; Rezende, F.C. Caracterização do tomateiro submetido ao déficit hídrico. Scientia Agraria, v.16, n.1, p.9-17, 2015. https://doi.org/10.5380/ rsa.v16i1.41042.

Peixoto, J.V.M.; Campos, L.F.C.; Moraes, E.R.; Cardoso, A.F.; Lana, R.M.Q.; Nascimento, A.R. Characterization of processing tomato lines as the physiological and production characteristics. Bioscience Journal, v.33, n.4, p.850-860, 2017a. https://doi. org/10.14393/BJ-v33n4a2017-36705.

Peixoto, J.V.M.; Silva Neto, C.M.; Campos, L.F.C.; Dourado, W.S.; Nogueira, A.P.O.; Nascimento, A.R. Industrial tomato lines: morphological properties and productivity. Genetics and Molecular Research, v.16, n.2, p.1-15, 2017b. https://doi.org/10.4238/gmr16029540.

Rai, A.K.; Vikram, A.; Pal, S. Genetic characterization of tomato (Solanum lycopersicum L,) germplasm for yield and quality traits through principal component analysis. Research Journal of Agricultural Sciences, v.8, n.5, p.1171-1174, 2017. https://www. researchgate.net/publication/322330426. 09 Feb. 2019.

Ramos, A.R.P. Produtos de efeitos fisiológicos no desenvolvimento de plantas de tomate 'Giuliana', na produção e pós-colheita de frutos. Botucatu: Universidade Estadual Paulista, Faculdade de Ciências Agronômicas, 2013. 147 p. Tese Doutorado. http://hdl. handle.net/11449/103308. 17 Feb. 2019.

Ramos, A.R.P.; Amaro, A.C.E.; Macedo, A.C.; Sugawara, G.S. de A.; Evangelista, R.M.; Rodrigues, J.D.; Ono, E.O. Qualidade de frutos de tomate 'giuliana' tratados com produtos de efeitos fisiológicos. Semina: Ciências Agrárias, v.34, n.6, p.3543-3552, 2013. https:// doi.org/10.5433/1679-0359.2013v34n6supl1p3543.

Schwarz, K.; Resende, J.T.V.; Preczenhak, A.P.; Paula, J.T.; Faria, M.V.; Dias, D.M. Desempenho agronômico e qualidade físico-química de híbridos de tomateiro em cultivo rasteiro. Horticultura Brasileira, v.31, n.3, p.410418, 2013. https://doi.org/10.1590/S0102-05362013000300011.

Siddiqui, M.W.; Ayala-Zavala, J.F.; Dhua, R.S. Genotypic variation in tomatoes affecting processing and antioxidant properties. Critical Reviews in Food Science and Nutrition, v.55, n.13, p.1819-1835, 2015. https://doi.org/10.1080/10408398.2012.710278.

Silva, A.R.; Dias, C.T.S. A cophenetic correlation coefficient for Tocher's method. Pesquisa Agropecuária Brasileira, v.48, n.6, p.589-596. 2013. https://doi.org/10.1590/S0100-204X2013000600003.

Singh, D. The relative importance of characters affecting genetic divergence. The Indian Journal of Genetic and Plant Breeding, v.41, n.2, p.237-245, 1981. http://www.indianjournals.com/ijor.aspx?ta rget=ijor:ijgpb\&volume=41\&issue=2\&article=010. 09 Mar. 2018.

Souza, L.M.; Melo, P.C.T.; Luders, R.R.; Melo, A.M.T. Correlations between yield and fruit quality characteristics of fresh market tomatoes. Horticultura Brasileira, v.30, n.4, p.627-631, 2012. https://doi.org/10.1590/S0102-05362012000400011.

Taiz, L.;Zeiger, E.; Møller, I.M.; Murphy, A. Fisiologia e desenvolvimento vegetal. Porto Alegre: Artmed, 2017. 860p. 